\title{
A Rare Complication of Endobronchial
Ultrasonography-transbronchial Needle Aspiration: Endob ronchial Nodule
}

\author{
Endobronşiyal Ultrasonografi-Transbronşiyal İğne Aspirasyonunun Nadir Bir \\ Komplikasyonu: Endobronşiyal Nodül
}

Kemal Can Tertemiz', Nurcan Güler', Volkan Karaçam², Aylin Ozgen Alpaydin

\begin{abstract}
Endobronchial ultrasound-guided transbronchial needle aspiration (EBUS-TBNA) is a safe procedure with high diagnostic yield. However, complications related to EBUS-TBNA procedures are increasingly being reported. Common complications of EBUSTBNA include infectious complications, pneumothorax, bleeding, and pneumomediastinum. Although the frequency of complications varies among studies, complication rates are quite rare (0.15 - 1.44\%). One of the rare complications of EBUS-TBNA is the appearance of nodular lesions at the tracheobronchial puncture sites following EBUS-TBNA, namely "tracheobronchial puncture site nodular reaction" (TPNR). Here, we present three cases of TPNR, two of which were diagnosed with granulation tissue and one with malignancy. A biopsy must be taken in cases presenting with nodular lesion after EBUS.
\end{abstract}

Key words: Endobronchial ultrasonography, endobronchial nodular lesions, endobronchial granulation.

\section{Özet}

Endobronşiyal ultrason kılavuzluğunda transbronşiyal iğne aspirasyonu (EBUS-TBIA) yüksek tanısal verime sahip güvenli bir prosedürdür. Bununla birlikte, EBUS-TBIA prosedürleri ile ilgili komplikasyonlar giderek daha fazla rapor edilmektedir. EBUS-TBIA yaygın komplikasyonları arasında, enfeksiyöz komplikasyonlar, pnömotoraks, kanama ve pnömomediasten yer almaktadır. Komplikasyon sıklığı çalışmalar arasında değişmekle birlikte komplikasyon oranları oldukça nadirdir (\% 0.15 -\% 1.44). EBUS - TBIA' nın nadir komplikasyonlarından biri, EBUS-TBIA'yı takiben trakeobronşiyal delinme bölgelerinde nodüler lezyonların ortaya çıkmasıdır. "Trakeobronşiyal ponksiyon bölgesi nodüler reaksiyonu" (TPNR) olarak tanımlanır. Burada, tanısı ikisinde granülasyon dokusu, birinde malignite olan TPNR gelişen üç olguyu sunuyoruz. EBUS sonrası nodüler lezyon ile başvuran olguarda mutlaka biyopsi alınmalıdır.

Anahtar Sözcükler: Endobronşiyal ultrasonografi, endobronşiyal nodüler lezyonlar, endobronşiyal granülasyon.

\footnotetext{
'Department of Chest Diseases, Dokuz Eylül University Faculty of Medicine, İzmir, Turkey

${ }^{2}$ Department of Thoracic Surgery, Dokuz Eylül University Faculty of Medicine, İzmir, Turkey

'Dokuz Eylül Üniversitesi Tıp Fakültesi, Göğüs Hastalıkları Anabilim Dalı, İzmir

${ }^{2}$ Dokuz Eylül Üniversitesi Tıp Fakültesi, Göğüs Cerrahisi Anabilim Dalı, İzmir
}

Submitted (Başvuru tarihi): 15.03.2021 Accepted (Kabul tarihi): 20.04.2021

Correspondence (iletişim): Kemal Can Tertemiz, Department of Chest Diseases, Dokuz Eylül University Faculty of Medicine, İzmir, Turkey

e-mail: tkemalcan@yahoo.com 
Endobronchial ultrasound-guided transbronchial needle aspiration (EBUS-TBNA) is a highly effective, minimally invasive procedure for the sampling of mediastinal lymph nodes and central pulmonary masses (1). The importance of EBUS in the evaluation of mediastinal diseases has witnessed a gradual increase (2). The use of EBUS-TBNA sampling for the diagnosis and staging of mediastinal lesions has emerged as an alternative to mediastinoscopy, as the standard optimum approach to the preoperative staging of lung cancer (3). Despite the advantages of minimally invasive procedures, EBUS-TBNA has some complications, such as pneumothorax, hemorrhage and infection (4). Recently, a rare complication of EBUS-TBNA has been defined known as tracheobronchial puncturesite nodular reaction (TPNR) (5). We present here three cases of TPNR development following EBUS-TBNA.

\section{CASE}

Case 1: A 60-year-old male patient presented with threemonth of hoarseness. A left upper-lobe mass lesion and left hilar lymphadenopathy (11L) were detected on a thorax computed tomography (CT). An FDG (fluorodeoxyglucose)-PET (positron emission tomography)-CT scan revealed an FDG avid mass in the left upper lobe along with FDG avid left paratracheal (4L) and hilar (1 1 L) lymph nodes. An EBUS-TBNA of the lymph node stations was performed using an EB-530US EBUS bronchoscope (Fujifilm, Corporation, Tokyo, Japan) with a 22-gauge aspiration needle (Medi-Globe, Germany). The pathological diagnosis was atypical cells with suspicion of adenocarcinoma, and so a second EBUS-TBNA was performed three weeks later when biopsies were again taken from the $4 \mathrm{~L}$ and $11 \mathrm{~L}$ stations, and the final diagnosis was adenocarcinoma. During the procedure, a polypoid lesion was observed on the left lower lateral wall of the trachea where the TBNA was performed (4L station) (Figure 1), and a biopsy of the polypoid lesion revealed granulation tissue. The patient experienced no bleeding, fever or infection after the procedure. Systemic chemotherapy was initiated on the patient, who remains on oncological follow-up.

Case 2: A 62-year-old male patient was referred to our clinic for EBUS-TBNA. The patient had a history of lung squamous cell carcinoma and a right lower lobectomy. After four cycles of chemotherapy and radiotherapy, a thorax CT performed for the evaluation of treatment response revealed multiple progressive lymph nodes located in the right lower paratracheal (4R) and subcarinal (7) regions. A standard 22-gauge needle was used for the
EBUS-TBNA procedure (Medi-Globe, Germany), and the resulting biopsies taken revealed reactive lymph nodes. The patient was admitted 2 months later with increased dyspnea, and thorax CT revealed progression in mediastinal lymph nodes as well as an irregularity and increased thickness (invasion?) between the 4R lymph nodes and the right lateral wall of the trachea. Metabolic progression was detected in $4 R$ and 7 regional lymph nodes on a PET-CT, and a second EBUS-TBNA was planned. During the procedure, a polypoid lesion was observed on the right lower lateral wall of the trachea and a biopsy was taken (Figure 2) that was reported as granulation tissue. The patient experienced no bleeding, fever or infection after the procedure. One year later, significant regression was noted in the lymph nodes on a thorax CT. Follow-up of the patient is continuing in our oncology clinic.

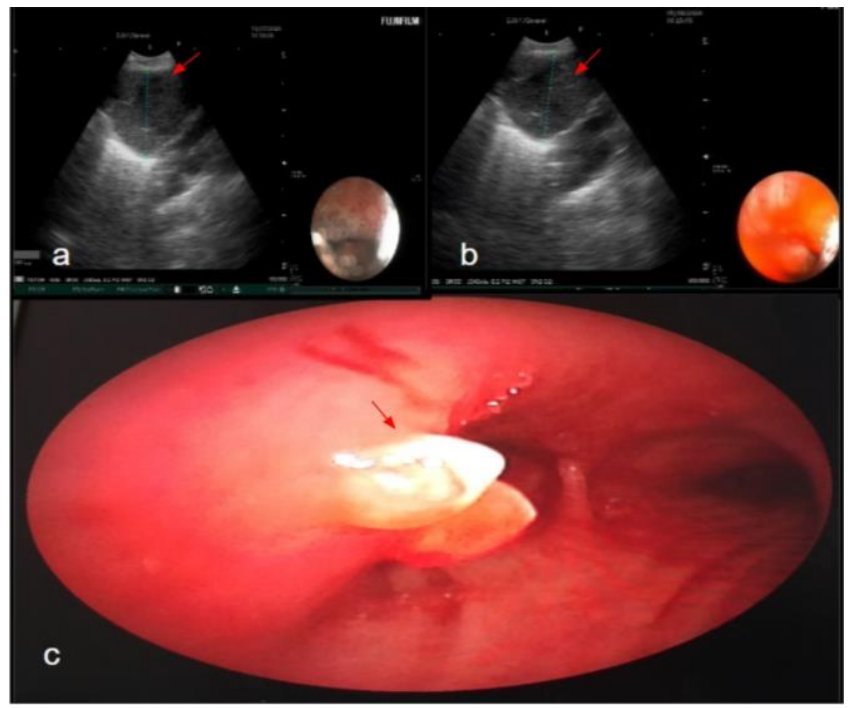

Figure 1: The appearance of the $4 L$ lymph node in the patient's first EBUS-TBNA procedure (a), view of the second EBUS-TBNA 4 L station 3 weeks later (b), endobronchial nodule in the left lower lateral tracheal wall (c)

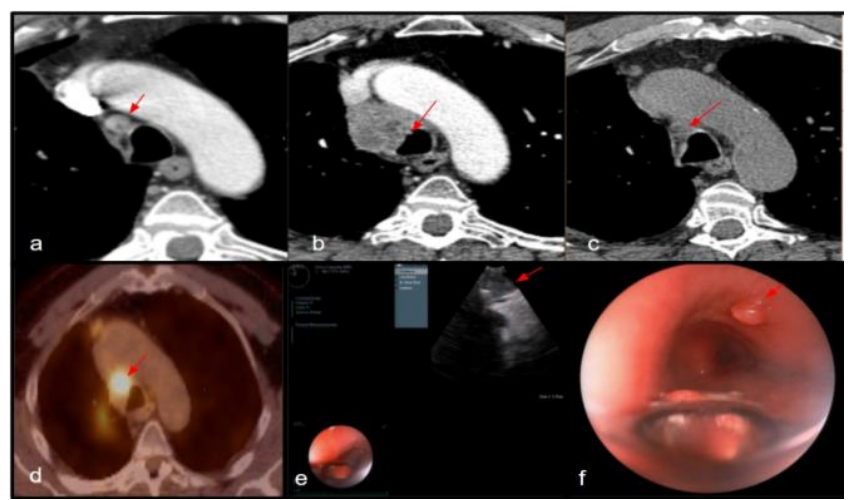

Figure 2: 4R station CT image (a), progression of the lymph node, irregularity in the tracheal wall (b), lymph node regression after systemic therapy (c), PET image (d), a sonographic image of EBUS (e), polypoid lesion in the wall of the trachea (f) 
Case 3: A 38-year-old male active smoker for 30 pack years presented with complaints of cough and weight loss for the previous 3 months. A thorax CT revealed a pulmonary nodule in the right upper lobe and lymphadenopathy in the $4 R$ and 7 stations. Biopsies were taken from the lymph nodes with a 22-gauge needle for the EBUS-TBNA procedure (Medi-Globe, Germany), which revealed non-small cell lung carcinoma. The patient experienced no bleeding, fever or infection after the procedure. Systemic chemotherapy was initiated, and the patient was admitted 2 months later with hemoptysis, and progression in the mediastinal lymph nodes and the mass lesion in the right upper lobe. Furthermore, a mass lesion of soft tissue density protruding into the right main bronchus, as well as a polypoid lesion, was seen on the anterior wall of the trachea on thorax CT. Flexible bronchoscopy revealed a nodular lesion in the area where the EBUS-TBNA was taken. A tracheobronchial stent was placed with rigid bronchoscopy and a biopsy was taken (Figure 3) revealing squamous cell carcinoma, and so the chemotherapy was continued. The patient died during follow-up from respiratory failure, four months after the last operation.

\section{DISCUSSION}

EBUS-TBNA remains as the first-line option when sampling mediastinal lymph nodes for histopathological diagnosis and for the staging of suspected lung cancer (6), and is known to be a reliable method based on its widespread use in recent years. Major complications after EBUS-TBNA (infection, pneumothorax, bleeding and perforation) were found in only $0.05 \%$ of cases in a meta-analysis of 190 studies, and no mortality (7). In a multicenter retrospective study, of the 3,123 patients evaluated, five had serious complications $(0.16 \%)$, determined as fever exceeding 24 hours, bronchogenic cyst infection, mediastinal abscess, pericarditis and pneumomediastinitis with empyema (8).

TPNR is a rarely described complication following EBUSTBNA. The first case reported in literature had polyps that were removed that presented with symptoms such as cough and shortness of breath (9). Later, an asymptomatic case entered spontaneous remission in the observed nodular lesion (10). Clinical diagnoses of inflammatory polyp or tumors should be considered in the differential diagnosis of a newly developed nodular lesion at the puncture site after EBUS-TBNA (1 1).

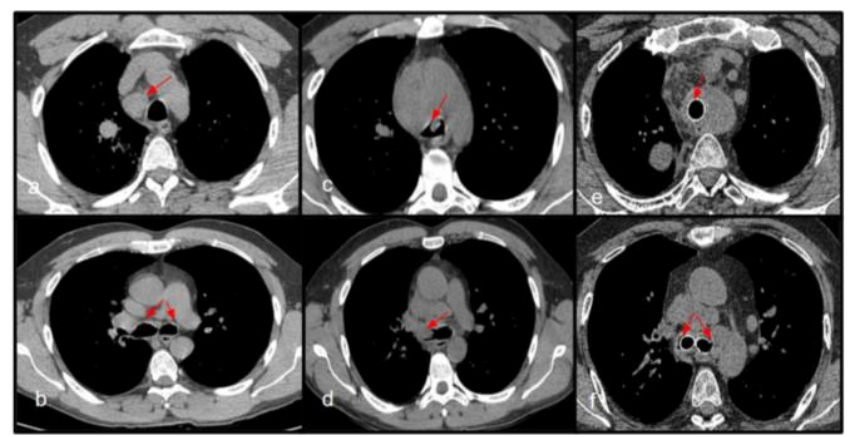

Figure 3: $4 R$ lymph node CT image (a), right and left main bronchi (b), polypoid lesion CT image (c) endobronchial lesion in the right main bronchus (d), polypoid lesion debulking endobronchial treatment, trachea and bilateral main bronchi stent placement $(e, f)$

TPNR was detected in three of the 1,067 patients who underwent EBUS-TBNA between 2016 and 2020 in our clinic, although an accurate number of TPNR cases cannot be reported since repeat bronchoscopies or EBUS were rare. For our first and second cases, we opted for follow-up since the pathological diagnosis was granulation tissue and the cases were asymptomatic. In the third case, on the other hand, endobronchial treatment was started for the newly developed nodular lesion due to dyspnea and hemoptysis.

The frequency of nodular lesion development after EBUSTBNA is as yet unknown. Among the publications on this subject in the form of case reports (9-12), some describe the implantation of a tumor or infection after a bronchoscopic procedure. Lee et al. reported on a case with tuberculous lymphadenitis who developed a new granuloma with a sinus tract after EBUS-TBNA. (12). Hu et al. (13) reported on a case of nasopharyngeal metastasis of lung cancer after bronchoscopic interventions, and Kim et al. (11) presented a case of TPNR development after EBUS-TBNA, the pathology of which squamous metaplasia and granulation tissue. The current knowledge of tumor seeding due to EBUS-TBNA is as yet insufficient, and there is thus a need to share further experiences on this subject.

The use of EBUS-TBNA is becoming more common with the increasing number of cancer cases recently, which may result in the identification of previously undefined complications in the future. We recommend a biopsy to distinguish between malignant benign granulation tissue in patients presenting with TPNR, as a recently defined rare complication of EBUS-TBNA. The course of cases with complications after EBUS-TBNA is a new research topic in this field. 


\section{CONFLICTS OF INTEREST}

None declared.

\section{AUTHOR CONTRIBUTIONS}

Concept - K.C.T., N.G., V.K., A.O.A.; Planning and Design - K.C.T., N.G., V.K., A.O.A.; Supervision - K.C.T., N.G., V.K., A.O.A.; Funding -; Materials -; Data Collection and/or Processing -; Analysis and/or Interpretation V.K.; Literature Review - V.K.; Writing - N.G., K.C.T.; Critical Review - A.O.A.

\section{YAZAR KATKILARI}

Fikir - K.C.T., N.G., V.K., A.O.A.; Tasarım ve Dizayn K.C.T., N.G., V.K., A.O.A.; Denetleme - K.C.T., N.G., V.K., A.O.A.; Kaynaklar -; Malzemeler -; Veri Toplama ve/veya İşleme -; Analiz ve/veya Yorum - V.K.; Literatür Taraması - V.K.; Yazıyı Yazan - N.G., K.C.T.; Eleştirel Inceleme - A.O.A.

\section{REFERENCES}

1. Bibbo M, Wilbur D. Comprehensive Cytopathology EBook. Elsevier Health Sciences; 2014.

2. Fuso L, Varone F, Magnini D, Calvello M, Lo Greco E, Richeldi L. Ultrasonography of the mediastinum: techniques, current practice, and future directions. Respir Care 2018; 63:1421-38. [CrossRef]

3. Walker CM, Chung JH, Abbott GF, Little BP, El-Sherief $A H$, Shepard J-AO, et al. Mediastinal lymph node staging: from noninvasive to surgical. Am J Roentgenol AJR 2012; 199:W54-W64. [CrossRef]

4. Dhooria S, Aggarwal AN, Gupta D, Behera D, Agarwal R. Utility and safety of endoscopic ultrasound with bronchoscope-guided fine-needle aspiration in mediastinal lymph node sampling: systematic review and metaanalysis. Respir Care 2015; 60:1040-50. [CrossRef]

5. Madan K, Tiwari P, Arava S, Hadda V, Mohan A, Guleria R. Tracheobronchial puncture-site nodular reaction (TPNR) following endobronchial ultrasound-guided transbronchial needle aspiration (EBUS-TBNA): Systematic review of case reports. Lung India 2017; 34:532-7. [CrossRef]
6. Leyn PD, De Leyn P, Dooms C, Kuzdzal J, Lardinois D, Passlick B, et al. Revised ESTS guidelines for preoperative mediastinal lymph node staging for non-small-cell lung cancer. Eur J Cardio-Thoracic Surg 2014; 45:787-98. [CrossRef]

7. Bartheld MB von, von Bartheld MB, van Breda A, Annema JT. Complication Rate of Endosonography (Endobronchial and Endoscopic Ultrasound): A Systematic Review. Respiration 2014; 87:343-51. [CrossRef]

8. Çağlayan B, Yılmaz A, Bilaçeroğlu S, Cömert SŞ, Demirci NY, Salepçi B. Complications of Convex-Probe Endobronchial Ultrasound-Guided Transbronchial Needle Aspiration: A Multi-Center Retrospective Study. Respir Care 2016; 61: 243-48. [CrossRef]

9. Gupta R, Park HY, Kim H, Um S-W. Endobronchial inflammatory polyp as a rare complication of endobronchial ultrasound-transbronchial needle aspiration. Interactive CardioVasc Thoracic Surg 2010; 11:340-1. [CrossRef]

10. Lee KM, Jang SM, Oh SY, Do Young K, Lee G, Kim A, et al. The Natural Course of Endobronchial Inflammatory Polyps as a Complication after Endobronchial Ultrasound-Guided Transbronchial Needle Aspiration. Tuberc Respir Dis 2015; 78:419-22. [CrossRef]

11. Kim SH, Lee Y, Park S, Choi CM, Jo J, Lee JC. Endobronchial mass formation after endobronchial ultrasoundtransbronchial needle aspiration mimicking implantation metastasis. Clin Case Rep 2015; 3: 983-986. [CrossRef]

12. Lee J-W, Kim W-J, Park C-W, Kang H-W, Ban H-J, Oh I$J$, et al. Endotracheal tuberculous granuloma formation following endobronchial ultrasound transbronchial needle aspiration. Intern Med 2013; 52: 1207-10. [CrossRef]

13. Hu J-B, Jin M, Chen E-G, Sun X-N. Lung squamous cell carcinoma metastasizing to the nasopharynx following bronchoscopy intervention therapies: a case report. World J Surg Oncol 2014; 12: 68. [CrossRef] 